\title{
UM ANO EXTRAORDINÁRIO: GREVES, REVOLTAS E CIRCULAÇÃO DE IDEIAS NO BRASIL EM 1917
}

\author{
An extraordinary year: strikes, uprisings and \\ circulation of ideas in Brazil in 1917 \\ Un año extraordinario: huelgas, revueltas y \\ circulación de ideas en Brasil en 1917
}

EDILENE TOLEDO

Edilene Toledo é mestre e doutora em História pela Universidade Estadual de Campinas e professora de História do Brasil do Departamento de História da Universidade de São Paulo (edilene.toledo@uol.com.br)

Artigo recebido em 31 de janeiro e aprovado para publicação em 26 de abril de 2017. 


\title{
RESUMO
}

Este artigo analisa, a partir de pesquisa original e dos estudos já realizados, as greves e revoltas ocorridas em São Paulo, Rio de Janeiro, Recife, Porto Alegre e outras cidades do Brasil em 1917 e suas reivindicações, a participação dos trabalhadores e dos militantes anarquistas e socialistas nesses eventos, e a circulação das ideias políticas no período, em especial os primeiros impactos no país das revoluções ocorridas na Rússia naquele ano, e como essas novas ideias revolucionárias começaram a transformar os grupos políticos e as organizações dos trabalhadores. As greves daquele ano tiveram um papel basilar para o desenvolvimento posterior do movimento operário e das lutas trabalhistas no Brasil.

Palavras-CHAVE: greve, 1917, movimento operário, anarquismo, Revolução Russa, comunismo.

\begin{abstract}
Based on an original research and on existing studies, this article analyzes the strikes and revolts that took place in São Paulo, Rio de Janeiro, Recife, Porto Alegre and other cities of Brazil in 1917 and their demands, the participation of workers, anarchist and socialist militants in these events, and the circulation of political ideas in the period, specially the first impacts in Brazil of the revolutions that occurred in Russia that year and how these new revolutionary ideas began to transform political groups and workers' organizations. The strikes held in that year were of fundamental importance for the later development of the labor movement and the labor struggles in Brazil.
\end{abstract}

KeYwORDs: strike, 1917, labor movement, anarchism, Russian Revolution, communism.

\section{RESUMEN}

En este artículo se analiza, desde una investigación original y estudios previos, huelgas y revueltas en São Paulo, Rio de Janeiro, Recife, Porto Alegre y otras ciudades de Brasil en 1917 y sus reivindicaciones, la participación de los trabajadores y militantes anarquistas y socialistas en estos eventos y la circulación de las ideas políticas en el período, sobre todo los primeros impactos en el país de las revoluciones que se produjeron en Rusia ese año y cómo estas nuevas ideas revolucionarias comenzaron a transformar los grupos políticos y las organizaciones de trabajadores. Las huelgas de 1917 tuvieron un papel fundamental en el desarrollo de las luchas de los trabajadores e del movimiento obrero en Brasil.

Palabras Clave: huelga, 1917, movimiento obrero, anarquismo, Revolución Rusa, comunismo. 


\section{INTRODUÇÃO}

E m julho de 1917, uma greve de enormes proporções, envolvendo cerca de 100 mil trabalhadores, homens, mulheres e crianças, paralisou São Paulo e, com a violência policial e o agravamento contínuo da situação dos operários, transformou a cidade em palco de uma verdadeira revolta urbana, a ação mais espetacular do movimento operário brasileiro até então (Biondi, 2011; Lopreato, 2000).

A greve teve início no bairro da Mooca, na zona leste de São Paulo, área de concentração de indústrias e de trabalhadores, no Cotonifício Crespi, no dia 8 de junho de 1917. Na fábrica Crespi, cerca de 400 operários iniciaram o movimento reivindicando um aumento salarial de 15 a 20\% e protestando contra a extensão do horário de trabalho noturno, imposto pela fábrica para atender ao aumento da produção e ocasionado também pela desestabilização da economia mundial causada pela guerra. ${ }^{1}$

A paralisação foi decidida pelos operários da fábrica, reunidos na Liga Operária da Mooca. A fábrica ameaçou demitir todos os trabalhadores se não voltassem ao trabalho, mas o movimento continuou e, a partir dessa primeira fábrica, foi se ampliando dia a dia e tomou enormes proporções nas semanas que se seguiram, atingindo seu auge no mês de julho.

À greve geral de São Paulo seguiram-se várias outras em diversas partes do país. Verdadeiras multidões saíram às ruas para protestar e reivindicar. Manifestações quase diárias ocorreram em várias cidades contra o alto custo de vida, o trabalho de crianças, os baixos salários e tantos outros problemas que afligiam os trabalhadores no Brasil. Elas foram organizadas pelos próprios trabalhadores e contaram com a participação de lideranças sindicalistas, anarquistas, socialistas e de outros grupos descontentes com a situação do país. As greves de algumas categorias e cidades certamente encorajavam outras a fazer também seu movimento, e a grande imprensa de várias cidades revelou claramente seu temor quanto a isso.

Essas greves e manifestações foram parte dos tantos movimentos de trabalhadores ocorridos ao redor do mundo naquele ano. Os últimos anos da Primeira Guerra Mundial e os primeiros do pós-guerra, em especial o ano de 1917, foram marcados por um ciclo de agitação social global (Pereira, 2014). Em todos os países atingidos pela desestabilização 
da economia, houve protestos contra a carestia e uma onda de greves envolvendo grande número de trabalhadores. Em muitos casos, o epicentro dos movimentos foram as áreas industriais das cidades.

Em várias partes do mundo, houve uma percepção coletiva da oportunidade de melhorar as condições de vida e de trabalho na crescente intervenção do Estado nas áreas econômica e social, na apropriação de formas de organização como associações de bairro e redes informais familiares e comunitárias na mobilização dos trabalhadores e da população e em mediações entre diferentes repertórios de ação coletiva, como as lutas em torno da produção e do consumo (Pereira, 2014). Golden (1985) afirma que há uma relação simbiótica entre a luta da classe trabalhadora moderna e os laços de solidariedade construídos nas comunidades locais, argumentando que os sindicatos, compartilhando o mesmo espaço com outras organizações de bairro, tenderam a tornar-se instituições comunitárias.

Alguns autores dão ênfase em seus estudos à ação da comunidade urbana, compreendida em termos espaciais, e à criação de fortes laços comunitários nos bairros. É o caso de Roger Gould (1995) em sua análise da Comuna de Paris de 1871, na qual considera que a solidariedade de vizinhança e de residência foi fundamental para a organização da ação revolucionária, que, na sua leitura, foi baseada em redes sociais e formas de organização preexistentes, num contexto específico de uma comunidade urbana sitiada. Segundo Gould, foi o fato de as reformas urbanas terem dispersado os trabalhadores, afastando-os do centro e empurrando-os para os novos bairros periféricos, que levou a uma estruturação social baseada mais no local de residência do que na ocupação, ao contrário de 1848, quando a classe teria desempenhado papel central.

Gould defende assim a ideia de que as identidades coletivas variam de acordo com as circunstâncias políticas e que 0 tratamento reducionista das redes na pesquisa dos movimentos sociais pode obscurecer aspectos importantes de seus efeitos sobre a mobilização. A mobilização da Comuna, para ele, foi simultaneamente afetada por mais de uma rede, não só aquelas criadas por organizações formais, mas também as informais, de vizinhança, enraizadas em laços sociais entre vizinhos, havendo uma interação, portanto, entre múltiplas redes. Autores como Gould apontam, portanto, para como as comunidades foram atores coletivos importantes em muitos eventos.

Ao analisar o cotidiano dos trabalhadores de Buenos Aires, Norberto Ferreras (2006) destaca que a exploração não estava restrita ao âmbito do trabalho, mas se intensificava em outras situações impossíveis de evitar, a alimentação e a habitação, que foram vivenciadas como parte de uma identidade comum dos trabalhadores. A percepção dessas experiências comuns relativas à moradia e aos alimentos foi fator de união importante entre os 
trabalhadores nas greves de 1917 no Brasil, e entre as reivindicações estavam justamente a diminuição do preço dos alimentos e dos aluguéis.

Joana Dias Pereira (2014) argumenta também que as "revoltas da fome" e as greves foram parte de um mesmo processo de mobilização e que sua articulação foi realizada pela ala mais radical do movimento sindical. A autora destaca ainda a relevância do papel das muIheres nesses movimentos, na gestão das redes de reciprocidade, familiares e de vizinhança. Nas greves ocorridas no Brasil, as mulheres também tiveram participação importante como trabalhadoras, militantes, mães, esposas e moradoras dos bairros populares.

Essas revoltas populares estiveram na origem de um novo ciclo de lutas trabalhistas. As populações pressionaram o Estado com o objetivo de impor uma economia moral. "A economia de guerra serviu para enfatizar as contradições fundamentais do sistema capitalista e da economia de mercado", observa Pereira. Emília Viotti da Costa (1998), em seu livro sobre a rebelião de escravos em Demerara em 1823, argumenta que "crises são momentos de verdade" porque evidenciam os conflitos que o cotidiano oculta, expondo as contradições.

Empregando o conceito de economia moral em oposição à economia de mercado, Thompson (1998) argumenta que a multidão algumas vezes conseguiu impor ao mercado um controle. Para ele essa economia moral se renova como crítica anticapitalista e como movimento de resistência. Argumenta também que não há uma relação direta fome-protesto. A fome no passado e no presente nem sempre levou a revoltas. A revolta é a resposta de um grupo, comunidade ou classe a uma crise. Mas não é a única nem a mais óbvia forma de ação coletiva. As greves e revoltas como as ocorridas no Brasil em 1917 foram uma resposta racional de grupos que se sentiram com algum poder para melhorar suas condições, ou mesmo para tomar os alimentos, como demonstram os saques ocorridos durante as greves. Para Thompson, a revolta não é uma resposta óbvia ou natural, mas um padrão sofisticado de comportamento coletivo, no qual os trabalhadores elaboram uma noção de justiça e uma teoria do direito à subsistência. 0 conflito sobre o direito de acesso aos alimentos, uma das dimensões importantes das greves de 1917, pode ser visto como um fórum de luta de classes.

No processo de luta se intensificou a formação de uma identidade nas comunidades, em oposição a proprietários, empregadores e comerciantes (Pereira, 2014). Nesse processo, os trabalhadores vão deixando de ver o Estado somente como um inimigo ou como fonte de opressão e passam a vê-lo como um instrumento importante para a obtenção ou consolidação de conquistas, o que tem consequências importantes na reorganização posterior do movimento operário. 


\section{Alguns aspectos das greVes em SÃo Paulo, Rio de JANeiro, Porto Alegre E ReCifE}

$\mathrm{O}$

Brasil e os outros países latino-americanos, apesar de distantes do palco da guerra, foram atingidos de diversos modos pelo conflito. Milhares de trabalhadores emigrados foram atingidos diretamente ao serem convocados a retornar a seus países como soldados (Toledo e Biondi, 2014). Além disso, a guerra elevou nesses países, exportadores de produtos agrícolas, os preços dos alimentos, o que afetava gravemente os trabalhadores, cujos salários não eram aumentados proporcionalmente, agravando sua situação de miséria. Em vários desses países, os empregadores também ampliavam as jornadas de trabalho, num contexto de intensificação da produção industrial.

Em junho de 1917, o recém-fundado jornal libertário A Plebe considerava que a propaganda feita em comícios e boletins estava produzindo bom efeito e esperava que os trabalhadores, "sujeitos agora, como nunca, a uma situação verdadeiramente intolerável", sentissem necessidade de agir. 0 jornal destacava a importância das reuniões que vinham sendo feitas em vários bairros operários para a formação de ligas e acrescentava: "Oxalá, pois, que o movimento promissor, agora em início, ganhe o devido vulto tão rapidamente quanto a gravíssima situação o exige", ${ }^{2}$ quase prevendo o que estava por vir.

A greve em São Paulo teve início, como vimos, na fábrica de tecidos de Rodolfo Crespi. Seus trabalhadores já trabalhavam 13 horas diárias, mas com o aumento da produção estavam sendo obrigados a trabalhar até as $23 \mathrm{~h}$ ou até a meia-noite. Recusando-se a aceitar esse prolongamento da já longa jornada, centenas de trabalhadores decidiram pela paralisação do trabalho. ${ }^{3}$ Eles não imaginavam que estariam dando início ao período de maior agitação do movimento operário até então, período que, segundo muitos historiadores, se iniciou naquele junho de 1917 e só terminou no início dos anos 1920, em meio a um amplo processo de organização dos trabalhadores (Biondi, 2011).

O conjunto do Cotonifício Crespi, na Mooca, tinha sido construído em 1897 e ocupava um quarteirão inteiro (Kuhl, 2008). A fábrica, cujo proprietário era o italiano Rodolfo Crespi, em 1912 empregava 1.305 operários, sendo 947 italianos. Destes, somente 234 eram homens; 223 eram mulheres maiores de 22 anos, 225 menores de 22 anos, e 243 eram crianças. ${ }^{4}$

A greve no Cotonifício Crespi inicialmente parecia ser um movimento isolado, como outros que tinham ocorrido em anos anteriores. 0 movimento, porém, tinha uma comissão de grevistas que vinha se reunindo na Liga Operária da Mooca, uma estrutura com centenas de integrantes que estava se enraizando naquele território operário. A Liga foi se tornando um ponto de referência para os trabalhadores e acabou funcionando como mediadora e 
coordenadora das negociações entre a comissão de grevistas e a direção da fábrica (Biondi, 2011). Nos dias seguintes, o movimento foi se expandindo e iniciaram-se greves de várias outras categorias. Em 30 de junho, os 1.600 operários da fábrica Ipiranga, do libanês Nami Jafet, também iniciaram uma greve. No dia 3 de julho, os socialistas do jornal Avanti! distribuíram 10 mil cópias de um manifesto convidando a população a se solidarizar com os grevistas (Biondi, 2011: 352). ${ }^{5}$

0 ponto máximo da agitação foi atingido no enterro do sapateiro José Gimenez Martinez, um jovem militante anarquista espanhol, que tinha apenas 21 anos e fazia parte do grupo Jovens Incansáveis. Mais de 10 mil pessoas participaram do cortejo fúnebre, que seguiu por vários pontos da cidade até o cemitério do Araçá. 0 cortejo foi interrompido por vários comícios. José Gimenez Martinez foi apenas uma das vítimas dos protestos, que chegaram a cerca de 200, segundo a investigação realizada pelo jornal Fanfulla no cemitério do Araçá nas noites de 15 e 16 de julho, quando a polícia fechou o cemitério para transportar os cadáveres. ${ }^{6}$

0 dia em que houve o maior número de operários em greve, quase 44 mil, foi o da apresentação pelo Comitê de Defesa Proletária, em comícios públicos, dos acordos estipulados. A greve se tornou generalizada somente nos dias em que a vitória de uma parte dos operários atraiu outros trabalhadores de pequenas e médias fábricas para o movimento. É importante destacar que os organizadores que constituíram o Comitê de Defesa Proletária eram familiares à população operária paulistana, o que explica a confiança depositada pelos trabalhadores na ação do Comitê e nas lideranças que o compuseram (Biondi, 2011).

Edgard Leuenroth, um dos principais membros do Comitê de Defesa Proletária, foi trabalhador gráfico e jornalista e um dos principais líderes anarquistas de São Paulo. 0 socialista italiano Teodoro Monicelli, também membro do Comitê, foi um dos principais oradores dos comícios realizados durante a greve. Tinha vindo para o Brasil em 1913 e foi por vários anos diretor do Avanti! de São Paulo (Toledo, 2004).

Em meio a comícios, passeatas, à tomada do centro pelos trabalhadores e moradores dos bairros operários, e aos embates com a polícia, foi se desenvolvendo a ação do Comitê de Defesa Proletária, ao mesmo tempo em que o secretário de Justiça, Eloy Chaves, ia se reunido com os empresários mais importantes da cidade envolvidos na greve. Uma comissão constituída por diretores de importantes jornais da grande imprensa funcionou como mediadora entre os empresários e o Comitê. Entre o sábado 14 e a segunda-feira 16 de julho, vários empresários foram assinando um acordo que reconhecia o direito de reunião, concedia aumento de $20 \%$ nos salários, garantia a libertação dos presos e proibia a demissão dos operários grevistas. ${ }^{7}$ 
No dia 21 de julho, o jornal anarquista $A$ Plebe noticiou o conjunto das reivindicações sistematizadas pelo Comitê de Defesa Proletária, após consulta a todas as "entidades de que fazem parte, expondo as aspirações não só da massa operária em greve como as aspirações de toda a população angustiada pelas prementes necessidades, considerando a insuficiência do Estado no providenciar de outra forma que não seja pela repressão violenta". Eram elas: a libertação dos grevistas presos, o respeito "do modo mais absoluto" ao direito de associação para os trabalhadores, nenhuma demissão por participação na greve, a abolição do trabalho de menores de 14 anos, a proibição do trabalho noturno para menores de 18 anos, a abolição do trabalho noturno das mulheres, o aumento de $35 \%$ para os salários inferiores a $5 \$ 000$ e de $25 \%$ para os superiores, o pagamento pontual a cada 15 dias, a garantia de trabalho permanente aos operários, a jornada de oito horas, a semana inglesa e o aumento de $50 \%$ em todo trabalho extraordinário, o imediato barateamento dos gêneros de primeira necessidade, bloqueando a ação de açambarcadores, a requisição, quando necessário, dos alimentos para a alimentação pública, medidas para impedir a adulteração e falsificação de produtos alimentares, e a redução do preço dos aluguéis. ${ }^{8}$

Apesar de até 0 jornal anarquista Guerra Sociale ter afirmado em 26 de julho que 0 movimento era uma "greve ligada mais à fome do que ao trabalho", 9 as reivindicações eram, em sua maioria, essencialmente trabalhistas.

o Correio Paulistano e o Jornal do Comércio foram os periódicos paulistanos que mais atacaram o movimento grevista, fazendo uma intensa campanha contra os anarquistas especialmente, considerados culpados pelo movimento, e reivindicando uma ação dura dos poderes públicos contra o que consideravam uma grave onda subversiva.

A greve se tornou o impulso para a formação de uma estrutura sindical mais enraizada. 0 processo de reorganização sindical foi influenciado também pela ação de coordenação desenvolvida pelo Comitê de Defesa Proletária, pelas ligas da Mooca e do Belenzinho, pela participação no Comitê de socialistas italianos do Centro Socialista Internazionale e por toda uma rede de associações políticas ou mutualistas italianas como os grupos republicanos, as lojas maçônicas e algumas sociedades italianas de socorro mútuo, que se solidarizaram com o movimento dos trabalhadores, apoiando-o também financeiramente (Biondi, 2011: 344).

Em 26 de agosto de 1917 foi refundada a Federação Operária de São Paulo, a FOSP. A greve geral de 1917, e as outras inúmeras greves daquele ano, tiveram um papel basilar e fundador para o desenvolvimento posterior do movimento operário e das lutas trabalhistas em São Paulo.

No Rio de Janeiro, também em julho de 1917, uma multidão invadiu moinhos, padarias e armazéns (Campos, 1988: 39). Uma mobilização intensa já se tinha iniciado desde janeiro 
daquele ano, com comícios em praças públicas contra a carestia, e nesse contexto várias categorias foram constituindo seus sindicatos, como os têxteis, metalúrgicos, marceneiros, trabalhadores da construção civil, entre outros.

No dia 18 de julho começaram a ser deflagradas várias greves envolvendo grande número de categorias, como os marceneiros, têxteis, sapateiros, padeiros, metalúrgicos, entre tantos outros, configurando uma greve geral. Foi a Federação Operária do Rio de Janeiro, a FORJ, que organizou o programa de reivindicações: salário mínimo e equiparação dos salários de mulheres e homens (Campos, 1988). Também ali a repressão foi intensa. Embora não tenha resultado em grandes conquistas para todas as categorias, as greves de julho foram muito importantes para a expansão e o fortalecimento das organizações sindicais, de características bastante heterogêneas, que iam de um sindicalismo mais propriamente reformista ao sindicalismo revolucionário e ao anarquismo.

Em Porto Alegre, as greves ocorreram entre 31 de julho e 4 de agosto de 1917. No dia 25 de julho, a greve geral de São Paulo tinha sido discutida em reunião da União Operária Internacional (UOI), organização que reunia operários ligados ao anarquismo. Antes ainda, desde o dia 21, a imprensa local vinha noticiando a preparação secreta da greve. No dia 29 de julho, um militante de São Paulo participou da reunião da Federação Operária do Rio Grande do Sul (FORGS), o que revela a circulação de militantes e ideias e o desejo de estender as greves e manifestações para o conjunto do país. Até então a FORGS tinha se declarado estranha ao movimento que se estava preparando. Pedreiros e carpinteiros foram os primeiros a se declarar favoráveis à greve (Silva Jr., 1996).

Em reunião na sede da FORGS, chamada sobretudo pela UOI, no dia 29, decidiu-se a criação da Liga de Defesa Popular, que encaminhou as reivindicações dos trabalhadores aos governos municipal e estadual. As reivindicações eram: diminuição dos preços dos produtos de primeira necessidade, providências para evitar o açambarcamento do açúcar, estabelecimento de um matadouro para fornecer carne à população a preços razoáveis, criação de mercados livres nos bairros operários, obrigatoriedade da venda do pão a peso e fixação semanal do preço do quilo, redução dos aluguéis, redução do preço do transporte, aumento de $25 \%$ dos salários, jornada de oito horas e de seis para mulheres e crianças. Houve muitas semelhanças, mas também diferenças em relação às reivindicações de São Paulo. Silva Jr. atribui essas diferenças a uma certa permeabilidade do Partido Republicano Rio-Grandense às reivindicações contra a carestia e ao fato de que tanto o governo municipal quanto o estadual tinham tomado algumas medidas para conter a alta dos preços de alguns produtos.

No dia 31 de julho organizou-se um grande comício onde se discutiu a carestia e a negociação com os governos municipal e estadual e se conclamou os trabalhadores a iniciar 
uma greve geral. Estima-se que mais de 30 mil trabalhadores entraram em greve. Cada categoria teve experiências diferentes ao longo da paralisação. 0 governo aceitou negociar, tabelou o preço dos alimentos e aumentou os salários dos trabalhadores a serviço do estado, propagando a incorporação do proletariado à sociedade e a eficácia da doutrina positivista na solução dos problemas sociais (Bartz, 2008: 191). Os decretos do governo estadual de Borges de Medeiros satisfizeram parcialmente as reivindicações, mas a greve continuou até que a repressão, com a ocupação militar da cidade, a inviabilizasse. 0 chefe de polícia e o intendente municipal mediaram as negociações e tanto aconselharam os empregadores a ceder quanto os trabalhadores a voltar ao trabalho. Silva Jr. Considera que foi reconhecida a legitimidade tanto da LDB quanto da FORGS. A LDB, criada na órbita dos anarquistas, passou a ter a participação de todos os sindicatos ligados à FORGS e foi mudando seus objetivos iniciais, o que evidencia os conflitos entre os grupos organizados do movimento operário.

Em Pernambuco, a greve se iniciou em Recife e se estendeu por várias outras cidades do estado, atingindo vários setores econômicos. Lá as lutas se intensificaram nos meses de agosto e setembro de 1917. As comemorações do Primeiro de Maio daquele ano evidenciam as difusão de ideias socialistas, e algumas categorias de trabalhadores, como os operários de fábricas de cigarros e marinheiros, iniciaram movimentos grevistas. A imprensa e a polícia anunciaram a presença na cidade de anarquistas argentinos, estranhos ao meio operário, fomentando as greves, e afirmaram que as greves ocorridas em São Paulo e no Rio de Janeiro tinham colocado a opinião pública em apreensão, pois se acreditava que a greve operária repercutiria fatalmente "no Norte", temendo-se a ocorrência das mesmas paralisações e protestos em Recife. Considerava-se, porém, que mesmo que ocorressem as greves não teriam um caráter anarquista, que seria contrário à índole do povo pernambucano, ainda que se reconhecesse que a situação do operariado brasileiro era muito precária. ${ }^{10}$

Os trabalhadores da Société du Port reivindicaram aumento de salário. O Sindicato de Ofícios Vários, reunindo os trabalhadores em praça pública, apresentou uma lista de suas reivindicações. No mesmo dia, em 15 de agosto, os operários calafates da Cory Brothers, empresa de rebocadores do porto de Recife, de ingleses, entraram em greve reivindicando aumento de salário de 20\%. Os empregados da prefeitura também reivindicaram aumento de salário. No fim de agosto, a ameaça de greve dos trabalhadores da Fábrica Paulista foi reprimida pela força policial. Foram ocorrendo protestos contra a carestia de vida, com a distribuição de boletins convidando os trabalhadores do comércio, os operários e a população em geral a participar, visto que as autoridades, como o governador do estado, nada tinham feito para amenizar os sofrimentos dos trabalhadores. Pedreiros e ajudantes também se declararam em greve. Moções de solidariedade foram feitas pelos alfaiates e outros (Moreira, 2005). 
Diversas categorias profissionais foram se juntando ao movimento. Na sede do Sindicato de Ofícios vários decidiu-se pela reivindicação de 50\% de aumento de salário. As operárias das fábricas de cigarro elaboraram um documento com reivindicações. Operários da Pernambuco Tramways também aderiram. A repressão policial provocou ferimentos em vários operários, inclusive crianças. Diversas associações, ligas e sindicatos redigiram documentos, com a liderança do Sindicato de Ofícios vários que se tornou também alvo da repressão. A polícia evacuou o sindicato e prendeu seu secretário. A cidade se transformou num campo de guerra (Moreira, 2005). A partir daí, a repressão dissolveu o movimento em Recife, mas as manifestações se estenderam a outras cidades do estado.

A Plebe noticiou o movimento do operariado na Bahia, considerando que também lá, assim como em São Paulo, Rio de Janeiro e Porto Alegre, os operários se encontravam em condições de fome e penúria "pela ação conjunta dos governantes e industriais do país". ${ }^{11}$

\section{UMA REFLEXÃO SOBRE AS REIVINDICAÇÕES}

s reivindicações dos trabalhadores nos protestos de 1917 eram, em termos gerais,
jornada de oito horas, semana de cinco dias e meio, fim do trabalho de crianças, restrições à contratação de mulheres e adolescentes, segurança no trabalho, pagamento pontual dos salários, aumento salarial, redução do preço dos aluguéis e do custo dos bens de consumo básicos, respeito ao direito de sindicalização, libertação dos trabalhadores presos durante as greves e recontratação de todos os grevistas demitidos. Essas reivindicações expressavam os interesses e necessidades dos trabalhadores e exigiam a ação tanto do Estado como dos empregadores, e nos dizem muito sobre as dificuldades da vida e do trabalho da população pobre das cidades naquele período, mas também sobre a mudança na relação com o Estado. Algumas reivindicações eram conjunturais, ligadas ao contexto específico, mas os trabalhadores aproveitaram a mobilização geral para trazer à tona outras antigas reivindicações ligadas a questões mais estruturais.

Em Recife, reivindicou-se também a equiparação do salário de mulheres e homens, a assistência dos empregadores em caso de acidente, doença ou velhice, a existência de higiene, ventilação e luz nos locais de trabalho, oficinas, hotéis, padarias e outros, e a redução dos preços dos transportes fluviais e terrestres (Moreira, 2005).

Nas fábricas, mas também nas oficinas e em outros empregos urbanos, as jornadas de trabalho eram longuíssimas, podiam chegar a 14 horas diárias e eram expandidas em períodos de produção intensa, como ocorreu em 1917. A jornada de 8 horas de trabalho era uma já antiga reivindicação do movimento operário internacional. Aqui no Brasil, em concomitância 
com movimentos em várias partes do mundo, os trabalhadores reivindicavam a redução da jornada de trabalho havia muito tempo, como ocorreu durante a greve geral deflagrada dez anos antes, em 1907, e organizada com esse escopo. Naquela ocasião, muitas categorias de trabalhadores conseguiram a jornada de 8 horas, mas as conquistas, como não eram escritas em leis e nem tinham fiscalização, em geral eram efêmeras, e os trabalhadores podiam perdê-las ou tinham que permanecer mobilizados para defendê-las.

A semana de 5 dias e meio também era uma reivindicação importante do operariado nacional e internacional. No Brasil, os trabalhadores não tinham folga semanal garantida por lei e em geral descansavam somente no domingo, ou nem mesmo no domingo. Reivindicavam então trabalhar de segunda a sexta e metade do sábado, de modo que pudessem ter algum tempo para repor as energias, cuidar das crianças e da casa.

0 fim do trabalho de crianças também estava entre as principais reivindicações do movimento operário brasileiro. Inúmeras fontes, inclusive as fotografias de fábricas e seus trabalhadores, evidenciam a enorme presença de crianças no mundo do trabalho do período, em especial nas indústrias têxteis. As crianças, que recebiam castigos físicos no interior da fábrica quando adormeciam ou brincavam durante suas longas jornadas de trabalho, recebiam salários muito inferiores aos dos adultos. Ao reivindicar o fim do trabalho infantil, os trabaIhadores organizados pretendiam não somente proteger suas crianças, mas também garantir maior poder de negociação para os trabalhadores adultos.

A regulamentação do trabalho das mulheres também era reivindicação antiga. As mulheres recebiam salários menores do que os homens, às vezes menos da metade, e, submetidas às mesmas condições de exploração, sofriam também com o assédio e até a violência sexual por parte de empregadores e contramestres. A proibição do trabalho noturno das mulheres era uma das principais reivindicações. Essas questões da vida das operárias de fábrica foram apresentadas por Patrícia Galvão, a Pagu, em seu romance proletário Parque industrial, publicado em 1933, retratando a vida de trabalhadoras de fábrica no bairro do Brás.

A questão da segurança no trabalho era também importante e uma reivindicação sempre presente. A questão aparece nos mais importantes espaços de discussão dos trabaIhadores no período, como durante os congressos operários nacionais ocorridos em 1906 e 1913. As fábricas eram fechadas e pouco arejadas, quase não tinham janelas e, por conseguinte, considerando as horas intermináveis de trabalho, os operários quase não viam a luz do sol. Nas fábricas têxteis, a aspiração contínua de poeira e fios predispunha os trabalhadores às doenças respiratórias, inclusive a tuberculose. Mas a principal preocupação era com os acidentes que ocorriam com frequência, muitas vezes causando a morte ou a 
amputação de membros, não havendo nesses casos nenhum tipo de proteção ao trabalhador ou à sua família, que podiam contar somente com as associações de socorro mútuo, os sindicatos ou parentes e vizinhos.

A questão do pagamento pontual dos salários também era amplamente debatida nos sindicatos e congressos operários. Também porque não havia nenhuma legislação ou controle, era comum que os empregadores atrasassem muito os pagamentos, lançando os trabalhadores em condições ainda mais miseráveis do que as habituais. Por isso eles também reivindicavam o pagamento semanal ou quinzenal.

0 aumento salarial era a principal reivindicação da greve. Como vimos, o enorme aumento do preço dos alimentos, no contexto da guerra, diminuiu ainda mais o poder aquisitivo dos trabalhadores, agravando sua situação de miséria, visto que os salários não foram aumentados na proporção dos preços e a situação foi ficando insustentável. Por isso, essa questão era central na luta dos trabalhadores e o principal objetivo das greves do período.

Associadas a tudo isso, estavam também as reivindicações de redução do preço dos aluguéis, que consumiam boa parte dos parcos salários, e do custo dos bens de consumo básicos, em especial dos alimentos. Os salários mal bastavam para o pagamento de aluguéis de casebres ou quartos em cortiços.

Enquanto muitas das reivindicações se referiam a questões propriamente trabalhistas, a questão da pressão sobre o governo e os empresários para a redução dos preços estava ligada mais a uma luta do cidadão, relacionada às necessidades da vida urbana e dos trabaIhadores na condição de consumidores, agravadas no contexto da guerra. Os trabalhadores pobres da cidade eram tanto os produtores quanto os consumidores de muitos dos produtos, como alimentos e tecidos, e tinham consciência plena dessa condição, o que ficava demonstrado pelas campanhas de boicote contra os produtos de fábricas de empregadores vistos como exploradores.

Questão também central na luta dos trabalhadores era a reivindicação do respeito ao direito de sindicalização. Tinha-se aqui uma luta trabalhista e uma luta do cidadão por um direito civil, o direito de se organizar e de se associar. Essa reivindicação apareceu explicitamente apenas nas reivindicações da greve em São Paulo.

Os trabalhadores não tinham muitas vezes nem ao menos o direito de reunião, havendo relatos na imprensa operária e memórias que revelam que nos períodos de repressão mais intensa os trabalhadores tinham que se reunir em casas de amigos, ou em matas nos arredores da cidade, ou chegavam a fazer as discussões caminhando, uma vez que qualquer reunião de pessoas poderia atrair a repressão policial. 
Algumas das reivindicações tinham relação direta com os movimentos grevistas daquele momento: a libertação dos trabalhadores presos durante as greves e a recontratação de todos os grevistas demitidos. A repressão contra os trabalhadores, como se sabe, já tinha longa história no país.

A análise das reivindicações nos permite afirmar que as greves foram movimentos com claros objetivos trabalhistas, que, por uma série de circunstâncias, levaram os trabaIhadores à exasperação e ao desespero, configurando-se os movimentos em verdadeiras revoltas urbanas. Militantes de várias correntes políticas, também operários ou não, juntaram-se aos trabalhadores em luta. Entre eles havia anarquistas, socialistas, sindicalistas revolucionários, reformistas e outros, mas havia também muitos que não estavam ligados a nenhumas dessas correntes, mas estavam mobilizados para tentar melhorar suas condições de trabalho e de vida.

Para Pereira (2014), os setores sociais mais atingidos pela carestia em 1917 viram no contexto uma oportunidade, e as ações coletivas foram direcionadas essencialmente às autoridades. Em muitos locais, as reivindicações dos trabalhadores e da população criaram fraturas no interior do Estado, quando parte dos administradores locais e da polícia com eles se solidarizou. Nos movimentos analisados, em Porto Alegre essa disposição do governo para negociar é mais perceptível, e em São Paulo foram relatados episódios de solidariedade da polícia. Também em São Paulo é mais perceptível uma ação ligada às comunidades dos bairros, já que podemos falar com mais certeza da zona leste da cidade como um território tipicamente estruturado pela indústria, onde se implantou um cinturão de indústrias definindo uma rígida barreira entre a cidade das elites e a ocupação periférica (Rolnik \& Frúgoli Jr.: 2001). Essas barreiras territoriais e sociais da cidade se evidenciam durante a greve geral de 1917. Em São Paulo também é mais clara a importância da participação da mulheres.

É certo que essas greves e revoltas não foram explosões repentinas de desespero. Os trabalhadores e as lideranças calculavam os riscos e os limites da negociação. As "revoltas da fome" ocorreram em comunidades com fortes relações de reciprocidade horizontal, de parentesco, de vizinhança e de locais de trabalho. Os protestos se voltaram sobretudo contra o aumento do preço dos alimentos e foram organizados a partir de redes sociais, mas as organizações políticas com relação estreita com as comunidades foram mobilizadas, ou se uniram aos protestos, e suas ideias e estratégias foram adaptadas. Então organizações de trabalhadores e redes informais se uniram transformando os protestos num movimento político único (Pereira, 2014), ainda que apresentassem particularidades de acordo com as condições políticas de cada local. 


\section{Alguns DebATES importantes: ESPONTANEIDADE E ORGANIZAÇÃO}

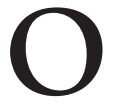

centro do debate historiográfico sobre as greves de 1917 no Brasil acabou sendo o grau de espontaneidade dos movimentos, polêmica que implicava a explicação das relações existentes entre a multidão de grevistas e os militantes anarquistas, socialistas e sindicalistas que participaram como lideranças dos movimentos.

Nos anos 1960 e 1970, nas interpretações sociológicas e históricas predominou a tese da espontaneidade e desorganização do movimento de 1917 (Rodrigues, 1966; Fausto, 1983), visto como uma explosão repentina motivada por fatores como a carestia e talvez pelas repercussões da Revolução Russa. Nessa mesma linha, considerou-se que os movimentos careciam de plano e objetivos previamente estabelecidos e de uma coordenação central.

Já nos anos 1980, os trabalhos passaram a reconsiderar a questão, à luz das transformações da historiografia proporcionadas pelo diálogo com a obra do historiador britânico Edward Palmer Thompson. Yara Aun Khoury (1981) considerou que a greve foi um capítulo importante na história da organização operária. Na mesma direção vai o trabalho de Cristina Hebling Campos (1988).

Cristina Lopreato (2000: 18) defendeu a tese de que o processo de autoconstituição das organizações operárias no interior de um amplo movimento de reivindicações impulsionado pela situação econômica e social do momento foi efeito do imenso trabalho de propaganda e da ação das diversas correntes anarquistas, o que teria tornado possível a operacionalização política da ação direta.

Luigi Biondi (2011: 316) argumenta é difícil negar a relevância do papel desempenhado pela crise econômica que se alastrava na determinação dos rumos do protesto. 0 autor considera ainda que a ausência de uma rede organizativa entre os empresários paulistanos também pode ter sido um fator que provocou uma lentidão no atendimento das reivindicações dos trabalhadores, desesperados por uma inflação diária jamais vista até aquele momento. Teria havido, portanto, uma incapacidade dos empregadores de compreender as necessidades e de fornecer uma plataforma comum de contrapropostas viáveis para as comissões de grevistas que iam se formando.

A ideia da espontaneidade não surgiu apenas da interpretação de alguns historiadores, mas remonta a parte importante das considerações que durante e após o movimento foram expressas pelos próprios líderes que participaram da greve, assim como por parte da imprensa, que manteve uma postura de simpatia e apoio aos grevistas, como foi o caso de Fanfulla, principal jornal da comunidade italiana de São Paulo, 0 Combate, e até mesmo 0 Estado de São Paulo. Biondi destaca que ainda em 1966 foi o próprio Edgard Leuenroth que, 
em carta publicado n'O Estado de São Paulo, sublinhou que a greve "foi um movimento espontâneo do proletariado, uma manifestação explosiva consequente de um longo período de vida tormentosa que então levava a classe trabalhadora" (Hall \& Pinheiro, 1981: vol. 2, 227). Biondi argumenta, porém, que o apelo à espontaneidade do movimento por causa de uma situação econômica de fato insuportável fazia parte de uma estratégia de driblar a repressão.

Emilia Viotti da Costa (1990) afirma que a ênfase no espontaneísmo e na importância das bases levou muitos autores a minimizar o papel das lideranças e a negligenciar fatores relevantes.

Segundo Luigi Biondi, os movimentos de protesto social ocorridos em muitas cidades europeias e americanas, aos quais se uniram greves reivindicativas e revoltas abertas, foram caracterizados por impulsos diversos, tanto espontâneos quanto organizados, que coexistiam e que constituíram o pano de fundo dessas agitações, cuja característica mais marcante foi a passagem da greve à revolta.

\section{AS PRIMEIRAS REPERCUSSÕES DA REVOLUÇÃO RUSSA EM 1917}

ssim que foi deflagrada, a Revolução Russa impressionou o mundo pela radicalidade
das ações dos revolucionários (Bartz, 2008). Muito cedo apareceram na imprensa operária comentários sobre os eventos ocorridos em março e em novembro de 1917, e muitos, incluindo os anarquistas, se entusiasmaram intensamente com a concretização dessa experiência revolucionária.

Emma Goldman já em 1917 observava que em seguida à vitória da revolução na Rússia, como um fantasma ameaçador, e às greves, instalou-se um clima "antivermelho" em várias partes do mundo (Lobo, 1983). 0 anticomunismo teria nascido junto com a Revolução Russa em 1917 (Motta, 2002). Em suas memórias, Tito Batini, filho de um socialista e futuro militante comunista, então com 13 anos, escreveu sobre o ano 1917 em São Paulo: "revolução na Rússia dos czares. Meu pai me leva à cantina de vinho Chianti. Brindamos o feito de um tal Lenin, que os jornais dizem não passar de um bandido" (Batini, 1991).

Deportada para a Rússia em 1919, do entusiasmo pela revolução Emma passou à percepção da ruptura entre libertários e bolcheviques, estes últimos considerando os anarquistas como representantes de um movimento pequeno-burguês e decadente em vias de desaparecer (Lobo, 1983: 70).

No Brasil, o impacto dos acontecimentos da Rússia foi muito intenso, gerando grandes polêmicas e despertando também grandes esperanças (Feijó, 1990). Grande parte do movimento operário, incluindo os anarquistas, acolheu com entusiasmo as notícias que chegavam 
sobre a queda do czar e a tomada do poder pelos bolcheviques. Lima Barreto chegou a afirmar que "a face do mundo mudou" (Bandeira, 1980: 327).

Em Alagoas, por exemplo, já em março de 1917 Antonio Canellas, no jornal A Semana Social, do qual era redator e tipógrafo, procurava analisar o desenrolar da revolução na Rússia prevendo que, "se o gênio mau da burguesia não impedir", haveria a "ramificação da árvore generosa que acaba de despontar na Rússia - a árvore da liberdade". ${ }^{2}$

Uma série de matérias do jornal A Plebe, logo após os eventos da greve geral de São Paulo, focalizou e explorou a possibilidade de uma junção de forças e a inserção de soldados no movimento "como na Rússia". ${ }^{13}$ Também convidou os opressores do proletariado no Brasil a lembrar "da França de 1789 e da Rússia de 1917", em tom ameaçador. ${ }^{14}$ Em dezembro de 1917, o barbeiro libanês Abílio de Nequete distribuiu panfletos em Porto Alegre com os quais tentava "congregar as duas classes", operários e soldados. ${ }^{15}$

Também em Porto Alegre, durante o maior comício da greve geral de 1917, João Batista Moll, militante anarquista, discursou com grande entusiasmo sobre a Rússia revolucionária (Bartz, 2008: 12). Adhemar Lourenço da Silva Jr. (1996) aponta vários exemplos em que, durante a greve, militantes, e também os anarquistas, fizeram a defesa da Revolução Russa. Abílio de Nequete foi o mais conhecido desses defensores, por ter fundado em Porto Alegre, já em 1918, a União Maximalista e, em 1922, ter-se tornado o primeiro secretário-geral do Partido Comunista do Brasil (PCB). Porém, ao menos até 1919, maximalistas ou comunistas e anarquistas atuaram juntos no Rio Grande do Sul (Bartz, 2008: 13), assim como no resto do país. Em agosto de 1917, o jornal anarquista A Plebe, de São Paulo, defendia a realização de um "Congresso Geral da Vanguarda Social do Brasil", convidando todas as associações "obreiras e avançadas" a participar da construção de uma ação conjunta. ${ }^{16}$

Astrojildo Pereira foi desde o início um dos maiores entusiastas da Revolução Russa no Brasil, escrevendo com pseudônimo para os jornais da grande imprensa textos em que contestava as interpretações hostis apresentadas pelos periódicos (Amaral, 2007). Já em 12 de julho de 1917, publicou na revista O Debate um texto intitulado "Sobre a Revolução Russa", no qual reconhecia a dificuldade de entender com precisão o curso dos acontecimentos na Rússia, sendo o "movimento de tal magnitude e complexidade, resolvido por mil correntes diversas", mas previa a preponderância contínua do proletariado "avançado, democrático, socialista e anarquista" e destacava a influência que tais acontecimentos exerceriam no resto do mundo. ${ }^{17}$ Ao referir-se a socialistas e anarquistas juntos, Astrojildo também apostava na unidade dessas correntes. Nos anos que se seguiram, porém, o impacto e o desdobramento da revolução na Rússia provocariam uma cisão entre as lideranças operárias e os trabalhadores no Brasil, tornando-se um divisor de águas em suas ideias. 
Essa transformação, porém, foi gradual. Astrojildo ainda em 1920 se declarava um libertário e doava dinheiro para o jornal anarquista $A$ Voz do Povo, que tinha substituído o Spartakus, que ele tinha escrito junto com José Oiticica. Embora mais tarde tenha escrito várias vezes que o declínio da influência libertária no movimento operário brasileiro se devia à sua incapacidade teórica e política de resolver os problemas da condução de um processo revolucionário, seu afastamento do anarquismo foi um processo doloroso (Amaral, 2007: 254).

José Oiticica tinha acompanhado as notícias vindas da Rússia e participado dos movimentos contra a guerra. Também entre os anarquistas crescia a esperança de um desdobramento no Brasil semelhante ao ocorrido na Rússia, e criavam-se expectativas nas organizações operárias de uma aliança entre soldados e trabalhadores, a exemplo também do fenômeno russo. Em junho de 1919, com delegados do Rio de Janeiro, Rio Grande do Sul, São Paulo e Alagoas, Oiticica presidiu no Rio de Janeiro uma conferência comunista que decidiu pela criação de um Partido Comunista com características nitidamente libertárias, acreditando ainda na possibilidade de uma ação conjunta e de um diálogo fecundo entre anarquistas e bolchevistas (Samis, 2007: 98). Joaquim Pimenta considerou que os anarquistas no Brasil se rebatizaram comunistas "sem talvez alcançar o grau das divergências que os separariam do Poder Soviético". ${ }^{18}$

Depois de algum tempo, e da chegada das notícias sobre a repressão contra os anarquistas na Ucrânia, Oiticica desacreditou da possibilidade dessa ação conjunta e retornou ao anarquismo propriamente, enquanto Astrojildo participou da fundação do PCB em março de 1922, iniciando o que ele considerava uma nova fase de luta do movimento operário brasileiro.

Já o farmacêutico alagoano Octávio Brandão iniciou sua militância, que o levaria ao anarquismo e mais tarde ao comunismo, justamente no ano de 1917, defendendo em jornais alagoanos uma posição antibélica, de solidariedade à revolução social e de simpatia crescente pela revolução ocorrida na Rússia. Brandão, que também viveu uma crise ideológica, defendeu a formação de uma frente única dos anarquistas com o PCB recém-fundado. Após alguns meses de leitura e reflexão e uma visita de Astrojildo na sua pequena farmácia, decidiu ingressar no PCB em outubro de 1922 (Amaral, 2007: 263).

Na maior parte do tempo em que o movimento operário no Brasil começava a tomar novos rumos, Edgard Leuenroth, a principal liderança do anarquismo em São Paulo, estava na prisão, acusado de ter promovido os saques contra o Moinho Santista. No primeiro número do jornal A Plebe, ele tinha exaltado os "formidáveis acontecimentos" que estavam se desenrolando "nas estepes geladas da longínqua Rússia". ${ }^{19}$ Ao ser libertado em 1921, retomou sua luta anarquista (Khoury, 2007), continuando a contrastar a ideia de que a organização político-partidária e a tomada do poder do Estado eram condições fundamentais para a 
transformação radical da sociedade. De qualquer modo, seja para afirmá-la seja para negá-la, a revolução na Rússia se tornou a principal referência do debate político das esquerdas e do movimento operário no Brasil a partir de 1917.

Muitos fatores explicam, portanto, a intensidade da agitação dos trabalhadores em várias partes do Brasil e do mundo no ano de 1917 e nos anos que se seguiram: o agravamento das condições de vida e de trabalho em virtude da Primeira Guerra Mundial, que aprofundou ainda mais a imensa desigualdade social; a propaganda desenvolvida pelas várias lideranças anarquistas, socialistas e sindicalistas revolucionárias; as atividades concretas de organização da classe trabalhadora com a criação de sindicatos, uniões, ligas e federações, e também a conjuntura internacional, marcada pela Revolução Russa e por uma onda revolucionária que atingiu a Europa. Esse ciclo de agitação global do período 1917-1920 teve um papel crucial na ampliação e politização do movimento operário em todo o mundo, e esses foram também os anos de maior mobilização dos trabalhadores na Primeira República, fundamentais para a construção dos trabalhadores como sujeitos políticos no Brasil. As experiências dos trabalhadores na Primeira República e em especial as do ano de 1917 foram capítulos importantes do processo de construção dos trabalhadores como sujeitos políticos (Gomes, 2002), da elaboração de uma cultura dos direitos, como os direitos civis de se organizar e se associar, e do esforço de criação de condições de democracia em que as organizações dos trabalhadores fossem reconhecidas como um elemento legítimo na sociedade. Ao mesmo tempo, muitos dos trabalhadores do período associaram um quotidiano reformista a uma perspectiva futura de transformação revolucionária no país.

\section{Notas}

1 Os números do jornal Fanfulla de junho e julho de 1917 mostram bem o desenrolar das greves.

2 Acção Obreira. 0 operariado paulista parece despertar para a luta. Movimentos grevistas. Associações que surgem. A Plebe, 09/06/1917, p. 3.

3 Nel Cotonificio Crespi, Fanfulla, 10/06/1917, p. 4.

4 Condições de trabalho na indústria têxtil no Estado de São Paulo. Boletim do Departamento Estadual do Trabalho. São Paulo, 1912 (citado por Hall e Pinheiro, 1981: 86-87).

5 Movimento operário. Avanti!, 20/10/1917, p. 2.

6 Voci allarmanti sul numero dei morti. Fanfulla, 22/07/1917, p. 2.

7 Fanfulla, 16/07/1917, p. 1.

80 que reclamam os operários. A Plebe, 21/07/1917, p. 3.

9 Guerra Sociale, 26/07/1917, p. 1, citado por Hall e Pinheiro (1979: 232). 
10 A Província, Recife, 29/07/1917 apud Moreira (2005: 48-49).

11 Movimento na Bahia. De como se prova o valor da acção popular. A Plebe, 11/08/1917, p. 3.

12 A Revolução Russa. Suas causas e suas possíveis consequências. A Semana Social, Maceió, 30/03/1917, p. 1.

13 Os soldados e os operários. A salvação do povo depende da acção conjunta dos operários de farda e de blusa. Para essa solução caminhamos. A Plebe, n. 11, 25/08/1917, p. 4, entre outros.

14 Momento Obreiro - Imponente despertar do operariado do paiz. De norte a sul o proletariado se agita contra os exploradores de seu trabalho - Grandiosa greve geral em Porto Alegre. As organizações de resistência surgem por toda parte. A Plebe, 04/08/1917, p. 3.

15 Inquérito Policial Militar 1432. Foro Federal. Porto Alegre (apud Bartz, 2008: 125).

16 Para uma acção conjunta. Congresso Geral da Vanguarda Social do Brazil. Preparem-se todas as associações obreiras e avançadas. A Plebe, 04/08/1917, p. 2.

17 Texto apresentado integralmente em Feijó (1990: 110-111).

18 Joaquim Pimenta. Retalhos do passado, apud Bandeira (1980: 252).

19 Edgard Leuenroth. Ao que vimos. Rumo à Revolução Social. A Plebe, 09/06/1917.

\section{REFERÊNCIAS BIBLIOGRÁFICAS}

AMARAL, Roberto Mansilla. Astrojildo Pereira e Octávio Brandão: os precursores do comunismo nacional. In: FERREIRA, Jorge \& Reis Filho, Daniel Aarão (orgs.). A formação das tradições 1889-1945. Rio de Janeiro: Civilização Brasileira, 2007 (Coleção As esquerdas no Brasil, vol. 1).

BANDEIRA, Moniz. O ano vermelho: a Revolução Russa e seus reflexos no Brasil. São Paulo: Brasiliense, 1980.

BARTZ, Frederico Duarte. O impacto da Revolução Russa no movimento operário do Rio Grande do Sul. 19171920. Dissertação de mestrado. Porto Alegre: Universidade Federal do Rio Grande do Sul, 2008.

BATINI Tito. Memórias de um socialista congênito. Campinas: Editora da Unicamp, 1991.

BIONDI, Luigi. Classe e nação. Trabalhadores e socialistas italianos em São Paulo, 1890-1920. Campinas: Editora da Unicamp, 2011.

BOTELHO, Denilson. A pátria que quisera ter era um mito: o Rio de Janeiro e a militância literária de Lima Barreto. Rio de Janeiro: Secretaria Municipal das Culturas, Departamento Geral de Documentação e Informação Cultural, Divisão de Editoração, 2002.

CAMPOS, Cristina Hebling. O sonhar libertário: movimento operário nos anos de 1917 a 1921. Campinas: Editora da Unicamp, 1988.

COSTA, Emília Viotti da. Estruturas versus experiência. Novas tendências na história do movimento operário e das classes trabalhadoras na América Latina: o que se perde e o que se ganha. Rio de Janeiro, BIB, n. 29, 1990.

—. Coroas de glória e lágrimas de sangue. São Paulo: Companhia das Letras, 1998.

FAUSTO, Boris. Trabalho urbano e conflito social. São Paulo: Difel, 1983. 
FEIJÓ, Martin Cezar. Formação política de Astrojildo Pereira. Belo Horizonte: Oficina de Livros, 1990.

FERRERAS, Norberto Osvaldo. O cotidiano dos trabalhadores de Buenos Aires (1880-1920). Niterói: EdUFF, 2006. GALVÃO, Patrícia. Parque industrial. São Paulo: José Olympio, 2006.

GOLDEN, Lester. The women in command. The Barcelona Womens' Consumer War of 1918.UCLA Historical Journal, 6, 1985, p. 5-32.

GOMES, Angela de Castro. Cidadania e direitos do trabalho. Rio de Janeiro: Zahar, 2002.

GOULD, Roger. Insurgent identities: class, community, and protest in Paris from 1848 to the Commune. Chicago: University of Chicago Press, 1995.

HALL, Michael \& PINHEIRO, Paulo Sérgio. A classe operária no Brasil. São Paulo: Brasiliense, 1981.

KHOURY, Yara Aun. As greves de 1917 em São Paulo e o processo de organização proletária. São Paulo: Cortez, 1981.

. Edgard Leuenroth, anarquismo e as esquerdas no Brasil. In: FERREIRA, Jorge \& REIS FILHO, Daniel Aarão (orgs.). A formação das tradições 1889-1945. Rio de Janeiro: Civilização Brasileira, 2007 (Coleção As esquerdas no Brasil, vol. 1).

KUHL, Beatriz Mugayar. Preservação do patrimônio arquitetônico da industrialização: problemas teóricos do restauro. Cotia, SP: Ateliê Editorial, 2008.

LOBO, Elisabeth Souza. Emma Goldman. A vida como revolução. São Paulo: Brasiliense, 1983.

LOPREATO, Christina da Silva Roquette. O espírito da revolta, a greve geral anarquista de 1917. São Paulo: Annablume, 2000.

MOREIRA, Aluizio Franco. A greve de 1917 em Recife. Clio - Revista de Pesquisa História, n. 23, 2005.

MOTTA, Rodrigo Patto Sá. Em guarda contra o "perigo vermelho": o anticomunismo no Brasil (1917-1964). São Paulo: Perspectiva, 2002.

PEREIRA, Joana Dias. 0 ciclo de agitação social global de 1917-1920, Ler História [Online], 66, 2014.

RODRIGUES, Leôncio Martins. Conflito industrial e sindicalismo no Brasil. São Paulo: Difusão Europeia do Livro, 1966.

ROLNIK, Raquel \& FRÚGOLI JR., Heitor. Reestruturação urbana da metrópole paulistana: a Zona Leste como território de rupturas e permanências. Cadernos Metrópole, n. 6, 2o semestre de 2001.

SAMIS, Alexandre. Presenças indômitas: José Oiticica e Domingos Passos. In: FERREIRA, Jorge \& REIS FILHO, Daniel Aarão (orgs.). A formação das tradições 1889-1945. Rio de Janeiro: Civilização Brasileira, 2007. (Coleção As esquerdas no Brasil, vol. 1)

SILVA JR., Adhemar Lourenço da. A greve geral de 1917 em Porto Alegre. Anos 90, Porto Alegre, n. 5, 1996.

THOMPSON, Edward Palmer. Economia moral revisitada. In: ——. Costumes em comum. Estudos sobre a cultura popular tradicional. São Paulo: Companhia das Letras, 1998.

TOLEDO, Edilene \& BIONDI, Luigi. Anarchism (Latin America). 1914-1918 online. International Encyclopedia of the First War http://encyclopedia.1914-1918-online.net/pdf/1914-1918-Online-anarchism_latin_america-2014-10-08.pdf 
